\title{
Skala i struktura inwestycji zagranicznych w polskim przemyśle
}

Brak dostatecznego kapitału krajowego w okresie transformacji sprawił, iż inwestycje zagraniczne stały się niezbędnym źródłem zasilania procesów rozwojowych kraju. Wraz z wejściem w życie ustawy z dnia 14 czerwca 1991 roku o spółkach z udziałem zagranicznym rozpoczął się stały dopływ do Polski kapitału zagranicznego w postaci inwestycji bezpośrednich (tab. 1).

Tabela 1. Całkowita wartość inwestycji zagranicznych poczynionych w Polsce w latach 1991-1997

\begin{tabular}{|c|c|c|c|}
\hline Lp. & Rok & $\begin{array}{c}\text { Kwota zainwestowana } \\
\text { (mln USD) narastająco }\end{array}$ & $\begin{array}{c}\text { Dynamika } \\
\text { Rok poprz. =100 }\end{array}$ \\
\hline 1. & 1991 & 470,0 &. \\
\hline 2. & 1992 & 1400,0 & 297 \\
\hline 3. & 1993 & 3000,0 & 214 \\
\hline 4. & 1994 & 4321,0 & 144 \\
\hline 5. & 1995 & 6832,2 & 158 \\
\hline 6. & 1996 & 12027,0 & 176 \\
\hline 7. & 1997 & 20587,7 & 171 \\
\hline
\end{tabular}

Źródło: Opracowanie własne na podstawie The List of Major Foreign Investors in Poland, 31 December 1997, PAIZ, Warszawa 1998

Z ogólnej sumy 20,6 mld USD nakładów aż 85\% stanowiły inwestycje duże, o wartości jednostkowej przekraczającej $1 \mathrm{mln}$ USD. Inwestycje tego rodzaju pozostają w szczegółowej ewidencji i nadzorze Polskiej Agencji Inwestycji Zagranicznych. Pozostałe $15 \%$ to inwestycje o mniejszej jednostkowej wartości, których łączna wielkość według szacunków PAIZ-u określana jest na około 2,9 mld USD (tab. 2).

W miarę upływu lat wartość inwestycji zagranicznych systematycznie rośnie, szczególnie intensywnie w latach 1995-1997. Tendencję wzrostową wykazuje również liczba inwestorów. W grudniu 1995 roku działało w Polsce 362 inwestorów zagranicznych, w grudniu 1996 roku - 492, a w końcu 1997 roku - 585 inwestorów z 30 państw. Wśród nich największą grupę stanowili inwestorzy z Niemiec - 134 (22\%), następnie kolejno z USA - 91, Francji - 51, Włoch - 44. Najmniejszą grupę, po 1 in- 
westorze, tworzą: Rosja, Singapur, Chiny, Słowenia, Chorwacja, Hiszpania, Czechy i RPA.

Tabela 2. Nakłady na wielkie i pozostałe inwestycje zagraniczne w Polsce w latach 1991-1997

\begin{tabular}{|c|l|c|c|c|}
\hline \multirow{2}{*}{ Lp. } & \multicolumn{1}{|c|}{ Wyszczególnienie } & \multicolumn{2}{|c|}{$\begin{array}{c}\text { Kwota zainwesto- } \\
\text { wana wg stanu } \\
\text { na 30.12.1997 }\end{array}$} & \multirow{2}{*}{ Założenia mln USD } \\
\cline { 2 - 4 } & \multicolumn{2}{|c|}{$\begin{array}{c}\text { Mln } \\
\text { USD }\end{array}$} & $\begin{array}{c}\text { Udział } \\
\%\end{array}$ & \\
\hline 1. & $\begin{array}{l}\text { Ogólna suma inwestycji } \\
\text { zagranicznych powyżej } \\
1 \text { mln USD }\end{array}$ & 17707,4 & 85,0 & \multirow{2}{*}{10777,1} \\
\hline 2. & $\begin{array}{l}\text { Szacunkowa suma inwestycji } \\
\text { zagranicznych poniżej } \\
1 \text { mln USD }\end{array}$ & 2882,3 & 15,0 & \\
\hline 3. & Ogólna suma & 20587,7 & 100,0 & 10777,1 \\
\hline
\end{tabular}

Źródło: jak w tabeli 1

Według wartości zainwestowanego kapitału pierwszą pozycję na liście największych inwestorów zagranicznych w Polsce opublikowanej przez PAIZ zajmują Stany Zjednoczone Ameryki Północnej. Do 1997 r. USA zainwestowały w naszym kraju 3981,8 mln USD, co stanowiło 22,5\% ogólnej wartości inwestycji zagranicznych. $\mathrm{Na}$ drugim miejscu znajdują się niemieccy inwestorzy (2 104,9 mln USD), a na trzecim instytucje międzynarodowe (1654,0 mln USD) jak np.: szwedzko-szwajcarskie ABB czy brytyjsko-duński Unilever. Końcową pozycje zajmowały: Luxemburg, Czechy, Grecja, Hiszpania, Słowenia. Kraje te zainwestowały odpowiednio 2,3 mln USD; 2,5 mln USD, 3,6 mln USD, $5 \mathrm{mln}$ USD, $6 \mathrm{mln}$ USD. Analiza danych potwierdza fakt dużej koncentracji źródeł pochodzenia kapitału.

Według stanu na grudzień 1997 roku 69\% kapitału pochodziło z 5 państw: USA, Niemiec, Włoch, Francji i Holandii. Państwa Unii Europejskiej zainwestowały w Polsce łącznie 9561,3 mln USD, co stanowi 54\% wszystkich inwestycji. W tym samym czasie azjatyccy inwestorzy zainwestowali tylko 1185,3 mln USD (6,7\%). Wzrastająca wartość inwestycji w 1997 roku była rezultatem zarówno inwestycji firm już obecnych na rynku polskim, jak i tych, które na nim się dopiero pojawiły.

Najwięcej kapitału zagranicznego ulokowane zostało w działalności produkcyjnej - 11042 mln USD, co stanowi około 62,4\% ogółu kapitału (tab. 3).

Największą popularnością wśród inwestorów zagranicznych cieszy się dział przemysłu: "produkcja wyrobów spożywczych, napojów i wyrobów tytoniowych" (3276,9 mln USD). Wiąże się to z tym, iż produkcja ta jest rentowna, ma zapewnione rynki zbytu oraz nie wymaga zbyt wysokich nakładów inwestycyjnych. Największym inwestorem jest koncern PepsiCo (412 mln USD), co dało mu piątą pozycję na liście największych inwestorów zagranicznych w Polsce. Jednocześnie do roku 2000 PepsiCo planuje dalsze inwestycje w Polsce o wartości $380 \mathrm{mln}$ USD. Do najważniejszych przyszłych inwestycji należy zaliczyć wykup udziałów w Zakładach w Pniewach produkujących Pepsi i w zakładach produkujących słone przekąski Frito-Lay w Grodzisku Mazowieckim. 
Inwestycje amerykańskiego koncernu Philip Morris, inwestora strategicznego w Zakładach Przemysłu Tytoniowego S.A. w Krakowie, osiagnęły w roku 1997 poziom 282 mln USD. W 1996 roku Philip Morris zapłacił 227 mln USD za 33\% akcji tego przedsiębiorstwa (z opcją na zakup dalszych $32 \%$ po zrealizowaniu warunków umowy).

Tabela 3. Wartość inwestycji zagranicznych w sekcjach i działach przemysłu

\begin{tabular}{|c|c|c|c|}
\hline Lp. & Wyszczególnienie & $\begin{array}{l}\text { Kwota zainwesto- } \\
\text { wana wg stanu na } \\
30.12 .97 \mathrm{mln} \text { USD }\end{array}$ & $\begin{array}{c}\text { Założenia } \\
\text { nowych inwestycji } \\
\text { mln USD }\end{array}$ \\
\hline 1. & Górnictwo i kopalnictwo & 16,2 & 0,0 \\
\hline 2. & Działalność produkcyjna, w tym: & 11042,0 & 5782,6 \\
\hline 2.1 . & $\begin{array}{l}\text { Produkcja wyr. spożywczych, napojów i wyr. } \\
\text { tytoniowych }\end{array}$ & 3276,9 & 1109,40 \\
\hline 2.2 . & Produkcja pojazdów mechanicznych & 2510,5 & 1969,50 \\
\hline 2.3 . & $\begin{array}{l}\text { Produkcja celulozowo-papiernicza, działal- } \\
\text { ność wydawnicza i poligraficzna }\end{array}$ & 1158,4 & 293,30 \\
\hline 2.4 . & Produkcja chemikaliów i wyr. chemicznych & 1087,4 & 518,0 \\
\hline 2.5 . & $\begin{array}{l}\text { Produkcja wyrobów z pozostałych surowców } \\
\text { niemetalicznych }\end{array}$ & 971,4 & 864,50 \\
\hline 2.6 . & $\begin{array}{l}\text { Produkcja maszyn i aparatury elektrycznej } \\
\text { i wyrobów optycznych }\end{array}$ & 664,4 & 260,8 \\
\hline 2.7. & Produkcja metali i wyrobów z metali & 375,3 & 184,3 \\
\hline 3. & Zaopatrywanie w energię elektryczną, gaz i wodę & 96,5 & 1040,0 \\
\hline
\end{tabular}

Źródło: jak w tabeli 1

Wartość inwestycji australijskiej firmy Coca-Cola Amantil sięga według stanu na koniec 1997 roku 285 mln USD. W ostatnim okresie przejęła ona większość polskich rozlewni od Coca-Cola Company Export Corporation, norweskiej firmy Ringnes i austriackiej Brau AG. Wykaz głównych inwestorów, którzy ulokowali swój kapitał w produkcję

wyrobów spożywczych, napojów i wyrobów tytoniowych zawiera tab. 4.

W dziale przemysłu "produkcja pojazdów mechanicznych" zainwestowano 2510,5 mln USD. Największym inwestorem zagranicznym zarówno w przemyśle motoryzacyjnym, jak i w ogóle w Polsce do 1997 roku był włoski koncern Fiat, który zainwestował 1141,9 mln USD w trzech spółkach: Fiat Auto Poland S.A., Magneti Marelli Poland S.A.

i Teksid Poland S.A. Inwestycje te polegały na wniesieniu do wymienionych spółek kapitału w wysokości 280,1 mln USD (w tym 261,5 mln USD stanowi kapitał wniesiony do Fiat Auto Poland S.A.) i spłaceniu do końca 1997 roku długu w wysokości $569 \mathrm{mln}$ USD.

Na drugim miejscu pod względem wielkości zaangażowanego kapitału jest południowokoreański koncern Daewoo, który łącznie zainwestował w Polsce 1011,3 mln USD - głównie w produkcję i montaż samochodów (Daewoo FSO w Warszawie, Daewoo Motor Poland w Lublinie). Największy koncern przemysłowy świata General Motors z USA zainwestował dopiero w 1998 roku w Gliwicach w uruchomienie fabryki produkującej Opla około $600 \mathrm{mln}$ DM (około $300 \mathrm{mln}$ USD). Zgodnie z porozumieniem z rządem RP przez następne dwa lata trwać będzie rozbudowa fabryki. Wówczas 
wartość inwestycji przekroczy $900 \mathrm{mln}$ DM (około $450 \mathrm{mln}$ USD). Powstała nowa fabryka Opla jest jedną z największych inwestycji w Polsce w latach 90. (tab. 5).

W dziale "produkcja celulozowo-papiernicza, działalność wydawnicza i poligraficzna" zainwestowano 1158,4 mln USD. Amerykańska firma IPC zainwestowała w Polsce $370 \mathrm{mln}$ USD. Od 1992 roku jest ona właścicielem Zakładów Celulozowo-Papierniczych S.A. w Kwidzyniu. Posiada również 35\% akcji Zakładów Papierniczych w Kluczach koło Olkusza oraz udziały Impap Sp. z o.o. Dzięki poczynionym przez IPC inwestycjom firma International Paper Kwidzyń stała się największym polskim producentem celulozy bielonej i białych papierów (tab. 6).

Tabela 4. Wykaz głównych inwestorów zagranicznych angażujących środki w dziale przemysłu: “produkcja wyrobów spożywczych, napojów i wyrobów tytoniowych” do końca 1997 r.

\begin{tabular}{|c|c|c|c|c|c|}
\hline Lp. & Inwestor & $\begin{array}{l}\text { Kwota zainwe- } \\
\text { stowana mln } \\
\text { USD }\end{array}$ & $\begin{array}{l}\text { Założenia } \\
\text { mln USD }\end{array}$ & $\begin{array}{l}\text { Rodzaj pro- } \\
\text { dukcji }\end{array}$ & Przejęte przedsiębiorstwa \\
\hline 1. & $\begin{array}{l}\text { PepsiCo } \\
\text { (USA) }\end{array}$ & 412,0 & 380,0 & $\begin{array}{l}\text { prod. } \\
\text { napojów }\end{array}$ & $\begin{array}{l}\text { Zakłady w Pniewach, zakłady } \\
\text { Frito-Lay w Grodzisku Mazo- } \\
\text { wieckim, Wedel S.A. }\end{array}$ \\
\hline 2. & $\begin{array}{l}\text { Coca-Cola } \\
\text { Amatil } \\
\text { (Australia) }\end{array}$ & 285,0 & 0.0 & $\begin{array}{l}\text { prod. } \\
\text { napojów }\end{array}$ & $\begin{array}{l}\text { Gdynia, Radzymin, Warszawa, } \\
\text { Niepołomice, Sr. Sląska, Lubin, } \\
\text { Łódź }\end{array}$ \\
\hline 3. & $\begin{array}{l}\text { Philip Morris } \\
\text { (USA) }\end{array}$ & 282,0 & 90,0 & $\begin{array}{l}\text { prod. wyr. } \\
\text { tytoniowych }\end{array}$ & $\begin{array}{l}\text { Zakłady Przemysłu Tytoniowego } \\
\text { S.A. w Krakowie }\end{array}$ \\
\hline 4. & $\begin{array}{l}\text { Nestle } \\
\text { (Szwajcaria) }\end{array}$ & 248,0 & 0,0 & $\begin{array}{l}\text { prod. wyr. } \\
\text { spożywczych }\end{array}$ & $\begin{array}{l}\text { udziały w: } \\
\text { Goplana S.A., Winiary S.A., Nestle } \\
\text { Sp. z o.o., Toruń Pacyfik CPP Sp. } \\
\text { z o.o., Nałęczowianka Sp. z o.o. }\end{array}$ \\
\hline 5. & $\begin{array}{l}\text { Cadbury's } \\
\text { Schweppes } \\
\text { (W. Brytania) }\end{array}$ & 50,0 & 0,0 & $\begin{array}{l}\text { prod. wyrobów } \\
\text { cukierniczych }\end{array}$ & $\begin{array}{l}\text { Cadbury's Polska Sp. z o.o. } \\
\text { we Wrocławiu }\end{array}$ \\
\hline 6. & $\begin{array}{l}\text { Bestfoods } \\
\text { (USA) }\end{array}$ & 30,0 & 18,0 & $\begin{array}{l}\text { prod. } \\
\text { koncentratów }\end{array}$ & $\begin{array}{l}\text { 99,9\% udziałów w Amino } \\
\text { Sp. z o.o. w Poznaniu }\end{array}$ \\
\hline 7. & $\begin{array}{l}\text { Gerber } \\
\text { (USA) }\end{array}$ & 30,0 & 0,0 & $\begin{array}{l}\text { przeróbka } \\
\text { żywności }\end{array}$ & Alima Rzeszów \\
\hline 8. & $\begin{array}{l}\text { E.B.S. } \\
\text { Montedison } \\
\text { (Włochy) }\end{array}$ & 30,0 & 58,0 & $\begin{array}{l}\text { prod. wyrobów } \\
\text { tłuszczowych }\end{array}$ & $\begin{array}{l}\text { Zakłady Tłuszczowe } \\
\text { Kruszwica }\end{array}$ \\
\hline 9. & $\begin{array}{l}\text { Mc Vitie's Group } \\
\text { United Biscuits } \\
\text { (W. Brytania) }\end{array}$ & 16,0 & 14,0 & $\begin{array}{l}\text { prod. wyrobów } \\
\text { cukierniczych }\end{array}$ & $\begin{array}{l}\text { 99,7\% udziałów w zakładach } \\
\text { Przemysłu Cukierniczego } \\
\text { SAN Sp. z o.o. w Jarosławiu }\end{array}$ \\
\hline 10. & $\begin{array}{l}\text { Intersnack } \\
\text { Knabber Gebaeck } \\
\text { GmbH\& Co.K.G. } \\
\text { (Niemcy) }\end{array}$ & 15,0 & 15,0 & prod. przekąsek & $\begin{array}{l}\text { Chio Lilly Snack Foods Ltd. } \\
\text { Sp. z o.o. w Warszawie, } \\
\text { fabryka chrupek w Nysie }\end{array}$ \\
\hline 11. & $\begin{array}{l}\text { Alpa } \\
\text { (Austria) }\end{array}$ & 16,0 & 0,0 & prod. napojów & Alpa Sp. z o.o. w Żywcu \\
\hline 12. & $\begin{array}{l}\text { Dr Oethker } \\
\text { (Niemcy) }\end{array}$ & 12,0 & 0,0 & $\begin{array}{l}\text { prod. koncen- } \\
\text { tratów }\end{array}$ & $\begin{array}{l}\text { Dr Oethker Środki Odżywcze } \\
\text { Gdańsk } \\
\text { Oliwa Sp. z o.o. }\end{array}$ \\
\hline 13. & $\begin{array}{l}\text { Orkla Foods A.S. } \\
\text { (Norwegia) }\end{array}$ & 11,8 & 0,0 & $\begin{array}{l}\text { przeróbka } \\
\text { żywności }\end{array}$ & $\begin{array}{l}65 \% \text { udziałów Kotlin } \\
\text { Sp. z o.o. }\end{array}$ \\
\hline 14. & $\begin{array}{l}\text { Kruger GmbH } \\
\text { (Niemcy) }\end{array}$ & 11,2 & 0,0 & $\begin{array}{l}\text { prod. koncen- } \\
\text { tratów }\end{array}$ & Kruger Polska Sp. z o.o. \\
\hline 15. & $\begin{array}{l}\text { Barilla } \\
\text { (Włochy) }\end{array}$ & 11,2 & 0,0 & prod. żywności & Danuta S.A. w Malborku \\
\hline 16. & Wasa & 11,0 & 0,0 & prod. pieczywa & Wasa Sp. z o.o. we Wrocławiu \\
\hline
\end{tabular}




\begin{tabular}{|c|l|c|c|l|l|}
\hline & (Szwecja) & & & chrupkiego & \\
\hline 17. & $\begin{array}{l}\text { Hochland } \\
\text { Niemcy) }\end{array}$ & 10,5 & 0,0 & prod. serów & Hochland Polska Sp. z o.o. \\
\hline 18. & $\begin{array}{l}\text { Nutricia } \\
\text { (Holandia) }\end{array}$ & 5,0 & 0,0 & $\begin{array}{l}\text { przeróbka } \\
\text { mleka }\end{array}$ & $\begin{array}{l}\text { Ovita Nutricia Sp. z o.o. } \\
\text { w Warszawie i Opolu; 66\% } \\
\text { udziałów w Okręgowej Sp. Mle- } \\
\text { czarskiej w Węrowie }\end{array}$ \\
\hline
\end{tabular}

Źródło: jak w tabeli 1

Tabela 5. Wykaz głównych inwestorów zagranicznych angażujących środki w dziale przemysłu: "produkcja pojazdów mechanicznych" do końca 1997 r.

\begin{tabular}{|c|c|c|c|c|c|}
\hline Lp. & Inwestor & $\begin{array}{l}\text { Kwota } \\
\text { zainwe- } \\
\text { stowana } \\
\text { mln USD }\end{array}$ & $\begin{array}{l}\text { Założe- } \\
\text { nia mln } \\
\text { USD }\end{array}$ & Rodzaj produkcji & Przejęte przedsiębiorstwa \\
\hline 1. & $\begin{array}{l}\text { Fiat } \\
\text { (Włochy) }\end{array}$ & 1141,9 & 814,7 & $\begin{array}{l}\text { prod. } \\
\text { samochodów }\end{array}$ & $\begin{array}{l}\text { FSM Bielsko-Biała, Fiat } \\
\text { Auto Poland Teksid, } \\
\text { Magneti Marelli Poland }\end{array}$ \\
\hline 2. & $\begin{array}{l}\text { Daewoo } \\
\text { (Korea) }\end{array}$ & 1011,3 & 567,4 & $\begin{array}{l}\text { prod. min. } \\
\text { samochodów }\end{array}$ & $\begin{array}{l}\text { Daewoo FSO Motor } \\
\text { w W-wie, } \\
\text { Daewoo Motor Polska } \\
\text { w Lublinie }\end{array}$ \\
\hline 3. & $\begin{array}{l}\text { Ford Motor } \\
\text { Comp. } \\
\text { (USA) }\end{array}$ & 54,0 & 45,0 & $\begin{array}{l}\text { montaż } \\
\text { samochodów }\end{array}$ & $\begin{array}{l}\text { Ford Poland S.A. } \\
\text { w Płońsku }\end{array}$ \\
\hline 4. & $\begin{array}{l}\text { Isuzu } \\
\text { (Japonia) }\end{array}$ & 35,7 & 159,3 & & fabryka w Tychach \\
\hline 5. & $\begin{array}{l}\text { Volvo Bus } \\
\text { Corporation } \\
\text { (Szwecja) }\end{array}$ & 23,1 & 0,0 & $\begin{array}{l}\text { montaż } \\
\text { samochodów }\end{array}$ & $\begin{array}{l}\text { Volvo Bus Poland Sp. } \\
\text { z o.o. we Wrocławiu } \\
\text { (11,2 mln USD) } \\
\text { Volvo Track Poland } \\
\text { Sp. z o.o. w W-wie } \\
\text { (10.7 mln USD) } \\
\text { Volvo Auto Poland } \\
\text { Sp. z o.o. w W-wie }\end{array}$ \\
\hline
\end{tabular}

Źródło: jak w tabeli 1

W dziale przemysłu "produkcja chemikaliów i wyrobów chemicznych" zainwestowano 1087,4 mln USD.

Największymi inwestorami zagranicznymi w przemyśle chemicznym są:

- brytyjsko-duński Unilever, który posiada 100\% akcji Polleny Bydgoszcz,

- Michelin (Francja) - główny udziałowiec zakładów "Stomil” w Olsztynie

- Good Year Tyre \& Rubber Company (USA) - posiada 50\% udziałów w Fabryce Opon Dębica S.A.

- Pliva d.d.(Chorwacja) - posiada ponad połowę udziałów w krakowskiej Polfie (tab. 7).

W dziale przemysłu "produkcja maszyn i aparatury elektrycznej i wyrobów optycznych" zainwestowano 664,4 $\mathrm{mln}$ USD. Zaangażowanie kapitału największego 
inwestora w tym dziale przemysłu koncernu ABB w Polsce na koniec 1997 roku wynosiło $282 \mathrm{mln}$ USD. Firma ta była też jednym z pierwszych inwestorów zagranicznych, którzy ulokowali swój kapitał w naszym kraju. Obecnie jest właścicielem m.in. zakładów Zamech

w Elblagu, Elmont w Łodzi, Elta (Fabryka Transformatorów), Elwa, Centrum i Dolmel we Wrocławiu, Zamech Zakład Urządzeń Ochrony Środowiska w Krakowie, Zamech Fabryka Rur Preizolowanych w Żorach. ABB planuje zainwestować w Polsce w ciaggu kilku najbliższych lat kolejne $258 \mathrm{mln}$ USD (tab. 8, 9).

Tabela 6. Wykaz głównych inwestorów zagranicznych angażujących środki w dziale: "produkcja celulozowo-papiernicza, działalność wydawnicza i poligraficzna" do końca 1997 r.

\begin{tabular}{|c|c|c|c|c|c|}
\hline Lp. & Inwestor & $\begin{array}{l}\text { Kwota } \\
\text { zainwe- } \\
\text { stowana } \\
\text { mln USD }\end{array}$ & $\begin{array}{l}\text { Założe- } \\
\text { nia mln } \\
\text { USD }\end{array}$ & Rodzaj produkcji & Przejęte przedsiębiorstwa \\
\hline 1. & $\begin{array}{l}\text { IPC } \\
\text { (USA) }\end{array}$ & 370,0 & 0,0 & prod. papieru & $\begin{array}{l}\text { International Paper - } \\
\text { Kwidzyń S.A.; Internatio- } \\
\text { nal Paper - Klucze S.A.; } \\
\text { Impap Sp. z o.o. }\end{array}$ \\
\hline 2. & $\begin{array}{l}\text { Framondi } \\
\text { (Austria) }\end{array}$ & 175,0 & 0,0 & prod. papieru & $\begin{array}{l}\text { 65\% udziałów w Zakła- } \\
\text { dach Celulozy i Papieru } \\
\text { "Celuloza S.A." }\end{array}$ \\
\hline 3. & $\begin{array}{l}\text { Intercellulosa } \\
\text { AB } \\
\text { (Szwecja) }\end{array}$ & 108,0 & 0,0 & $\begin{array}{l}\text { prod. celulozy, } \\
\text { papieru i tektury }\end{array}$ & $\begin{array}{l}\text { Intercell S.A. - 43,0\% } \\
\text { udziałów w Ostrołęckich } \\
\text { Zakładach Celulozo- } \\
\text { wo-Pa-pierniczych, Scan- } \\
\text { box } \\
\text { w Łodzi, Nordic Box } \\
\text { w Tychach, } \\
\text { Intercell Trading Sp. z o.o. } \\
\text { w Warszawie }\end{array}$ \\
\hline 4. & $\begin{array}{l}\text { Kronospan } \\
\text { (Szwajcaria) }\end{array}$ & 106,0 & 150,0 & $\begin{array}{l}\text { prod. papieru } \\
\text { i mebli }\end{array}$ & $\begin{array}{l}\text { Malta Poznań, } \\
\text { Kronopol Sp. z o.o. } \\
\text { w Żarach } \\
\text { Kronospan Sp. z o.o. } \\
\text { w Szczecinku }\end{array}$ \\
\hline 5. & $\begin{array}{l}\text { GTE Interna- } \\
\text { tional (USA) }\end{array}$ & 26,4 & 0,0 & wydawca & $\begin{array}{l}\text { Panorama Polska Sp. z o.o. } \\
\text { (51,0\% udziałów) }\end{array}$ \\
\hline 6. & $\begin{array}{l}\text { Metsa Serla } \\
\text { (Finlandia) }\end{array}$ & 10,0 & 0,0 & prod. papieru & $\begin{array}{l}\text { Warszawskie Zakłady } \\
\text { w Konstancinie }(59,0 \% \\
\text { udziałów) }\end{array}$ \\
\hline 7. & $\begin{array}{l}\text { KZP Projekti } \\
\text { Uddevalla AB } \\
\text { (Szwecja) }\end{array}$ & 8,6 & 24,0 & prod. papieru & $\begin{array}{l}\text { Kostrzyn Paper S.A. } \\
\text { (85,75\% udziałów) }\end{array}$ \\
\hline
\end{tabular}

Źródło: jak w tabeli 1

Wartość inwestycji zagranicznych jest relatywnie niska w tych działach przemysłu, które z reguły są nośnikami postępu technicznego, innowacji i dynamicznego roz- 
woju przemysłu oraz innych dziedzin gospodarki. Do takich działów zaliczyć można np.: przemysł maszynowy, elektroniczny, elektorotechniczny, teletechniczny, precyzyjny, wysoko przetworzonej chemii. Sytuacja ta nie sprzyja porządnym przekształceniom struktury przedmiotowej polskiego przemysłu w kierunku jej unowocześnienia i poprawy efektywności ekonomicznej.

Nie jest również dobrze, iż na polskim rynku nieobecne są światowe koncerny oferujące zaawansowane technologicznie produkty. Brak jest $\mathrm{w}$ Polsce potentatów komputerowych, takich jak Microsoft, IBM czy Intel. Ich przedstawicielstwa zajmuja się jedynie sprzedażą, a nie produkcją. Spośród potentatów branży farmaceutycznej nie ma

takich koncernów na naszym rynku, jak Pfizer, Roche czy Schering-Plaugh.

Tabela 7. Wykaz głównych inwestorów zagranicznych angażujących środki w dziale przemysłu: “produkcja chemikaliów i wyrobów chemicznych” do końca 1997 r.

\begin{tabular}{|c|c|c|c|c|c|}
\hline Lp. & Inwestor & $\begin{array}{l}\text { Kwota } \\
\text { zainwe- } \\
\text { stowana } \\
\text { mln USD } \\
\end{array}$ & $\begin{array}{l}\text { Założe- } \\
\text { nia mln } \\
\text { USD }\end{array}$ & Rodzaj produkcji & $\begin{array}{l}\text { Przejęte przedsię- } \\
\text { biorstwa }\end{array}$ \\
\hline 1. & $\begin{array}{l}\text { Unilever } \\
\text { (Międzynarodo- } \\
\text { wy Koncern) } \\
\end{array}$ & 140,0 & 0,0 & $\begin{array}{l}\text { prod. m.in. } \\
\text { środków piorących }\end{array}$ & $\begin{array}{l}\text { Unilever Polska } \\
\text { w Warszawie, Pol- } \\
\text { lena Bydgoszcz }\end{array}$ \\
\hline 2. & $\begin{array}{l}\text { Michelin } \\
\text { (Francja) }\end{array}$ & 136,0 & 151,0 & prod. opon & $\begin{array}{l}\text { Stomil Olsztyn S.A. } \\
\text { Michelin Polska Sp. } \\
\text { z o.o. w Warszawie }\end{array}$ \\
\hline 3. & $\begin{array}{l}\text { Procter \& Gamble } \\
\text { (USA) }\end{array}$ & 131,6 & 190,0 & $\begin{array}{l}\text { prod. środków } \\
\text { higieny }\end{array}$ & $\begin{array}{l}\text { Zakłady w Warsza- } \\
\text { wie (Targówek) }\end{array}$ \\
\hline 4. & $\begin{array}{l}\text { GoodYear } \\
\text { Tyre \& Rubber } \\
\text { Company (USA) }\end{array}$ & 112,0 & 55,0 & prod. opon & $\begin{array}{l}50,0 \% \text { udziałów } \\
\text { w Fabryce Opon } \\
\text { Dębica S.A. }\end{array}$ \\
\hline 5. & $\begin{array}{l}\text { Pliva d.d. } \\
\text { (Chorwacja) }\end{array}$ & 100,0 & 70,0 & $\begin{array}{l}\text { prod. środków } \\
\text { farmaceutycznych }\end{array}$ & $\begin{array}{l}70,0 \% \text { udziałów } \\
\text { w Polfie - Kraków }\end{array}$ \\
\hline 6. & $\begin{array}{l}\text { Cussons Group } \\
\text { Ltd. } \\
\text { (W. Brytania) }\end{array}$ & 46,8 & 0,0 & $\begin{array}{l}\text { prod. środków } \\
\text { czystości }\end{array}$ & $\begin{array}{l}\text { Cussons Polska S.A. } \\
\text { we Wrocławiu, } \\
75,0 \% \text { udziałów } \\
\text { w Fabryce Kosme- } \\
\text { tyków Pollena Uroda } \\
\text { S.A. w Warszawie } \\
\end{array}$ \\
\hline 7. & $\begin{array}{l}\text { Henkel } \\
\text { KGaA } \\
\text { (Niemcy) }\end{array}$ & 36,5 & 0,0 & $\begin{array}{l}\text { prod. m.in. środ- } \\
\text { ków czystości } \\
\text { i kosmetyków }\end{array}$ & $\begin{array}{l}\text { 80,0\% udziałów } \\
\text { w Henkel Polska } \\
\text { S.A. w Raciborzu, } \\
\text { Henkel Cosmetics } \\
\text { Sp. z o.o. w Hele- } \\
\text { nówku }\end{array}$ \\
\hline 8. & $\begin{array}{l}\text { ICN } \\
\text { Pharmaceuticals } \\
\text { INC } \\
\text { (USA) } \\
\end{array}$ & 33,7 & 33,3 & $\begin{array}{l}\text { prod. środków } \\
\text { farmaceutycznych }\end{array}$ & $\begin{array}{l}80,0 \% \text { udziałów } \\
\text { w Polfie Rzeszów }\end{array}$ \\
\hline
\end{tabular}

Źródło: jak w tabeli 1 
Inwestycje zagraniczne w Polsce przeznaczone są w dużej mierze na prywatyzację przekształceniową, a nie "założycielską". Oznacza to, iż większość inwestorów zagranicznych przeznacza swoje środki na wykup części lub całości już istniejących przedsiębiorstw. Nieliczna grupa to inwestorzy tworzący w Polsce firmy "od podstaw" lub podejmujący w znacznej skali rozbudowę istniejącego potencjału produkcyjnego. Przykładem jest General Motors, który pod koniec 1998 roku przekazał do użytku ogromną inwestycję - nową fabrykę samochodów Opel w Gliwicach.

Zdaniem autora wszelkie ulgi inwestycyjne powinny być przyznawane tylko tym inwestorom, którzy podejmują w Polsce nowe inwestycje, rozwijając potencjał gospodarczy kraju i tworząc nowe miejsca pracy, a nie tym, którzy wykupują już istniejące przedsiębiorstwa.

Tabela 8. Wykaz głównych inwestorów zagranicznych angażujących środki w dziale przemysłu: "produkcja maszyn, aparatury elektrycznej i wyrobów optycznych" do końca 1997 r.

\begin{tabular}{|c|l|l|l|l|l|}
\hline Lp. & Inwestor & $\begin{array}{l}\text { Kwota zainwe- } \\
\text { stowana } \\
\text { mln USD }\end{array}$ & $\begin{array}{l}\text { Założe- } \\
\text { nia mln } \\
\text { USD }\end{array}$ & $\begin{array}{l}\text { Rodzaj pro- } \\
\text { dukcji }\end{array}$ & Przejęte przedsiębiorstwa \\
\hline 1. & $\begin{array}{l}\text { Daewoo } \\
\text { Korea) }\end{array}$ & - & - & $\begin{array}{l}\text { prod. urządzeń } \\
\text { elektronicz- } \\
\text { nych }\end{array}$ & $\begin{array}{l}\text { Daewoo Electronics \& } \\
\text { Machines w Pruszkowie }\end{array}$ \\
\hline 2. & $\begin{array}{l}\text { ABB (Mię- } \\
\text { dzynarodowy } \\
\text { Koncern) }\end{array}$ & 282,0 & 258,0 & $\begin{array}{l}\text { prod. m.in. } \\
\text { urządzeń elek- } \\
\text { tronicznych, } \\
\text { generatorów, } \\
\text { turbin }\end{array}$ & $\begin{array}{l}\text { udziały w 16 spółkach } \\
\text { joint-ventures }\end{array}$ \\
\hline 3. & $\begin{array}{l}\text { Thomson } \\
\text { Multi Media } \\
\text { (Francja) }\end{array}$ & 185,0 & 0,0 & $\begin{array}{l}\text { prod. telewi- } \\
\text { zyjnych lamp } \\
\text { elektronowych } \\
\text { i elektroniki } \\
\text { TV }\end{array}$ & $\begin{array}{l}\text { Polkolor Sp. z o.o. } \\
\text { Thomson - Lamina - } \\
\text { Lampy Elektronowe Sp. } \\
\text { z o.o. w Piasecznie koło } \\
\text { Warszawy }\end{array}$ \\
\hline 4. & $\begin{array}{l}\text { Philips } \\
\text { (Holandia) }\end{array}$ & 108,1 & 70,6 & $\begin{array}{l}\text { prod. elektro- } \\
\text { nicznych } \\
\text { urządzeń }\end{array}$ & $\begin{array}{l}\text { Philips Lighting Poland } \\
\text { w Pile, Philips Matsushita } \\
\text { Battery Poland S.A. } \\
\text { w Gnieźnie, Philips Con- } \\
\text { sumer Electronics Indu- } \\
\text { stries Poland w Kwidzy- } \\
\text { niu, } \\
\text { Philips Lightning Farel } \\
\text { Mazury w Kętrzynie, } \\
\text { Philips Lighting Bielsko, } \\
\text { Polam Pabianice, } \\
\text { Philips Poland w Warszawie }\end{array}$ \\
\hline 5. & $\begin{array}{l}\text { Curtis } \\
\text { (USA) }\end{array}$ & 100,0 & 0,0 & $\begin{array}{l}\text { prod. elektro- } \\
\text { niki }\end{array}$ & $\begin{array}{l}\text { Curtis International INC } \\
\text { w Warszawie, Curtis } \\
\text { Companies Ltd. - TV } \\
\text { produkcja w Mławie, Cur- }\end{array}$ \\
\hline
\end{tabular}




\begin{tabular}{|c|l|l|l|l|l|}
\hline & & & & $\begin{array}{l}\text { tis } \\
\text { Healthcare Co. Ltd. } \\
\text { w Poznaniu i w Warszawie }\end{array}$ \\
\hline 6. & $\begin{array}{l}\text { Legrand } \\
\text { (Francja) }\end{array}$ & 31,5 & 19,0 & $\begin{array}{l}\text { prod. elektr- } \\
\text { nicznego wy- } \\
\text { posażenia }\end{array}$ & $\begin{array}{l}\text { Legrand SNC w Warsza- } \\
\text { wie, 75,0\% udziałów } \\
\text { FAEL-ELFA w Ząbo- } \\
\text { wicach Śl. }\end{array}$ \\
\hline
\end{tabular}

Źródło: jak w tabeli 1

W przyszłości nie zmieni się istotnie kierunek inwestycji. Nadal najwięcej inwestycji poczynionych zostanie w działach "produkcja wyrobów spożywczych, napojów i wyrobów tytoniowych" oraz "produkcja pojazdów mechanicznych".

Tabela 9. Wykaz głównych inwestorów zagranicznych angażujących środki w dziale przemysłu: "produkcja wyrobów z pozostałych surowców niemetalicznych, produkcja metali i wyrobów z metali” do końca 1997 r.

\begin{tabular}{|c|c|c|c|c|c|}
\hline Lp. & Inwestor & $\begin{array}{l}\text { Kwota } \\
\text { za-inwesto } \\
\text { wana mln } \\
\text { USD } \\
\end{array}$ & $\begin{array}{l}\text { Założe- } \\
\text { nia mln } \\
\text { USD }\end{array}$ & Rodzaj produkcji & Przejęte przedsiębiorstwa \\
\hline 1. & $\begin{array}{l}\text { Pilkington } \\
\text { (W. Brytania) }\end{array}$ & 168,9 & 0,0 & prod. szkła & $\begin{array}{l}\text { Huta Sandomierz, Art- } \\
\text {-Glass IGP Małopolska } \\
\text { w Krakowie } \\
\end{array}$ \\
\hline 2. & $\begin{array}{l}\text { Lafarge } \\
\text { (Francja) }\end{array}$ & 150,0 & 200,0 & prod. cementu & $\begin{array}{l}\text { Lafarge Polska S.A. } \\
\text { w Warszawie, } 75,0 \% \\
\text { udziałów w Kombinacie } \\
\text { Cementowo-Wapienniczym } \\
\text { "Kujawy" w Bieławach, } \\
\text { 23,14\% w Cementowni } \\
\text { Małogoszcz w Kielcach }\end{array}$ \\
\hline 3. & $\begin{array}{l}\text { Dyckerhoff } \\
\text { (Niemcy) }\end{array}$ & 98,5 & 230,0 & prod. cementu & $\begin{array}{l}\text { 60,0\% udziałów w Ce- } \\
\text { men-towni Sitkówka No- } \\
\text { winy, 33,0\% w Cemen- } \\
\text { towni Małogoszcz } \\
\end{array}$ \\
\hline 4. & $\begin{array}{l}\text { Lucchini Group } \\
\text { (Włochy) }\end{array}$ & 80,8 & 111,4 & $\begin{array}{l}\text { prod. żelaza } \\
\text { i stali }\end{array}$ & $\begin{array}{l}\text { Huta Lucchini Warszawa } \\
\text { Sp. z o.o. }\end{array}$ \\
\hline 5. & $\begin{array}{l}\text { F\&P Holding } \\
\text { Company INC } \\
\text { (USA) } \\
\end{array}$ & 66,8 & 15,7 & & $\begin{array}{l}\text { 53,0\% udziałów Can-Pack } \\
\text { S.A. w Krakowie }\end{array}$ \\
\hline 6. & $\begin{array}{l}\text { Cimenteries } \\
\text { CBR } \\
\text { (międzynarodo- } \\
\text { wy koncern) }\end{array}$ & 54,0 & 33,0 & prod. cementu & $\begin{array}{l}\text { 30,\% udziałów Górażdże } \\
\text { S.A., Górażdże, Strzelce } \\
\text { CBR - Cementfund } \\
\text { Sp. z o.o., Cementownia } \\
\text { St. Opolskie S.A. (42,0\% } \\
\text { udziałów) } \\
\end{array}$ \\
\hline 7. & $\begin{array}{l}\text { Rugby Group } \\
\text { (W. Brytania) }\end{array}$ & 25,0 & 0,0 & prod. cementu & $\begin{array}{l}\text { 34,3\% udziałów w Ce- } \\
\text { mentowni Chełm S.A. }\end{array}$ \\
\hline
\end{tabular}




\begin{tabular}{|c|l|l|l|l|l|}
\hline 8. & $\begin{array}{l}\text { Akiebolaget } \\
\text { SKF (Szwecja) }\end{array}$ & 18,0 & 3,0 & $\begin{array}{l}\text { prod. toczonych } \\
\text { łożysk }\end{array}$ & $\begin{array}{l}\text { SKF Fabryka Łożysk To- } \\
\text { czonych S.A. w Poznaniu }\end{array}$ \\
\hline 9. & $\begin{array}{l}\text { Owen - Illinois } \\
\text { (USA) }\end{array}$ & 17,2 & 25 & prod. szkła & $\begin{array}{l}\text { 36,0\% udziałów Huta } \\
\text { Szkła w Jarosławiu }\end{array}$ \\
\hline 10. & $\begin{array}{l}\text { Braas } \\
\text { (Niemcy) }\end{array}$ & 15,3 & 13,7 & prod. mat. bud. & $\begin{array}{l}\text { Braas Polska Sp. z o.o., } \\
\text { Braas Systemy Dachów } \\
\text { Płaskich Sp. z o.o. } \\
\text { w Opolu }\end{array}$ \\
\hline 11. & $\begin{array}{l}\text { Timken Com- } \\
\text { pany (USA) }\end{array}$ & 12,5 & 12,0 & $\begin{array}{l}\text { prod. toczonych } \\
\text { łożysk }\end{array}$ & $\begin{array}{l}\text { Timken Polska Sp. z o.o. } \\
\text { w Sosnowcu }\end{array}$ \\
\hline 12. & $\begin{array}{l}\text { Bekaert NV } \\
\text { (Belgia) }\end{array}$ & 10,0 & 5,0 & $\begin{array}{l}\text { prod. wyrobów } \\
\text { metalowych }\end{array}$ & $\begin{array}{l}\text { Bekaert - Koltarnia Sp. } \\
\text { z o.o., Opole }\end{array}$ \\
\hline 13. & $\begin{array}{l}\text { SAPA } \\
\text { Szzwecja) }\end{array}$ & 10,0 & 2,5 & prod. wyr. alum. & $\begin{array}{l}\text { SAPA Poland Ltd. fabryka } \\
\text { w Trzciance Lubuskiej i Pile }\end{array}$ \\
\hline
\end{tabular}

Źródło: jak w tabeli 1

\section{Literatura}

Durka B., 1998, Inwestycje zagraniczne w Polsce, Warszawa

Dziewanowicz W., 1997, Kapitat zagraniczny a rozwój regionalny i lokalny w Polsce, Warszawa

Olesiński Z., 1998, Bezpośrednie inwestycje zagraniczne w Polsce, PWE, Warszawa

The List of Major Foreign Investors in Poland, 31 December 1997, PAIZ, Warszawa 1998

Woś B. 1997, Kapitał zagraniczny na Ślasku Opolskim w okresie transformacji systemowej, Instytut Śląski Sp. z o.o., Opole 